\title{
Reversión de la operación de Hartmann por vía laparoscópica
}

\author{
Álvaro Lavega, Emilia Cerchiari, Isabel Gabito, Alejandra Liz, Gonzalo \\ Gayo, Diego Lapiedra, Marcelo Viola \\ Unidad de Coloproctología, Clínica Quirúrgica “1” Hospital Pasteur Prof. Dr. Fernando \\ González Calcagno. Montevideo, Uruguay.
}

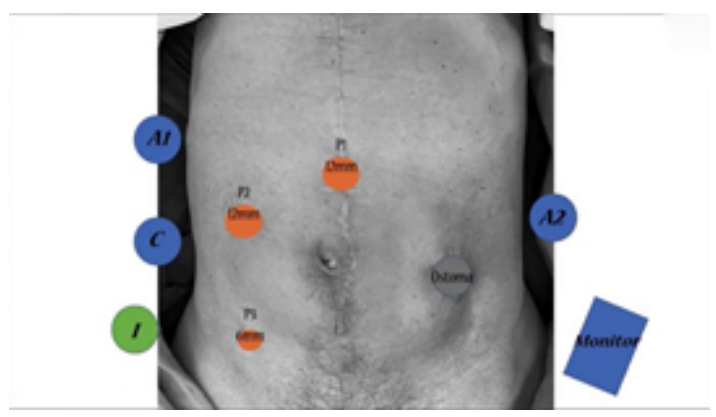

\section{RESUMEN}

Introducción: El procedimiento de Hartmann es una de las cirugías que se realizan con mayor frecuencia frente a una complicación oclusiva o perforativa de colon izquierdo; nos permite resolver el cuadro clínico de la complicación. El porcentaje de restitución del tránsito intestinal es muy bajo, promediamente inferior al $50 \%$. Esto se debe a factores propios del paciente, la morbimortalidad de la cirugía y a dificultades técnicas.

El restablecimiento del tránsito intestinal luego de un Hartmann puede llegar a ser una cirugía muy hostil. Tiene una morbimortalidad propia no despreciable, independientemente de la vía de abordaje utilizada.

La reversión por laparoscopía es uno de los procedimientos más complejos a realizar mediante este abordaje. Pero varios estudios han demostrado, que si bien requiere de una curva de aprendizaje más larga y un nivel de destreza técnica alto, tiene mejores resultados que el laparotómico.

Descripción del caso: Presentamos el caso clínico de un hombre de 65 años, que consultó por una peritonitis purulenta diverticular un año atrás, al cual se le realizó un procedimiento de Hartmann.

Se coordina para reconstrucción del tránsito intestinal por vía laparoscópica.

Paciente en decúbito dorsal, Trendelemburg $30^{\circ}$ y lateralizado a derecha.

Neumoperitoneo hasta $12 \mathrm{mmHg}$ por técnica abierta en flanco derecho para un puerto de $12 \mathrm{~mm}$, inicialmente para la cámara, y luego para la mano izquierda del cirujano. Otro de $6 \mathrm{~mm}$ en fosa ilíaca derecha, para la mano derecha del cirujano, y uno de $12 \mathrm{~mm}$ supraumbilical para la cámara.

Identificamos el muñón rectal en la pelvis.

Liberamos el ostoma circunferencialmente y confeccionamos una jareta con polipropileno 2-0.

Colocamos el anvil de la sutura mecánica $29 \mathrm{~mm}$, y reintroducimos el cabo colónico al abdomen. Se realiza cierre parietal en dos planos y reinstalamos el neumoperitoneo.

Colocamos la sutura mecánica transrectal, engarzando la misma con el anvil a través de la cara anterior del muñón rectal, confeccionando la anastomosis colorrectal término-lateral.

La prueba hidroneumática fue negativa. El paciente tuvo un postoperatorio sin complicaciones, otorgándole el alta a las 72 hs del procedimiento, tolerando vía oral, sin dolor, sin fiebre y habiendo movilizado el intestino.

Conclusiones: La cirugía de Hartmann sigue siendo uno de los procedimientos más realizados para tratar las complicaciones perforativas y oclusivas del colon izquierdo y recto.

La restitución del tránsito intestinal luego de esta cirugía tiene un altísimo porcentaje de no concretarse por diferentes motivos.

La cirugía miniinvasiva requiere de una larga curva de aprendizaje y destreza de alto nivel, pero hay varios trabajos que demuestran que la reversión de un Hartmann tiene mejores resultados por esta vía.

Palabras claves: Procedimiento de Hartmann; Cirugía laparoscópica; Cirugía miniinvasiva; Reversión Hartmann

\section{ABSTRACT}

Introduction: The Hartmann's procedure is one of the most frequently performed surgeries for an occlusive or perforative complication of the left colon, allowing the clinical picture to be resolved. The percentage of restitution of intestinal transit is very low, on average less than $50 \%$. This is due to factors specific to the patient, the morbidity and mortality of the surgery, and technical difficulties. Restoring intestinal transit after a Hartmann procedure can be a very hostile surgery. It has its own

Los autores del trabajo declaran no tener ningún conflicto de interés.

Marcelo Viola

mviolam@gmail.com

Recibido: septiembre de 2020. Aceptado: octubre de 2020. 
non-negligible morbidity and mortality, regardless of the approach used. Laparoscopic reversal is one of the most complex procedures to be performed using this approach. But several studies have shown that although this technique requires a longer learning curve and a high level of technical dexterity, it has better results than the laparotomic approach.

Case description: We present the clinical case of a 65-year-old man, who underwent a Hartmann's procedure a year ago for diverticular purulent peritonitis. A laparoscopic reconstruction of intestinal transit was decided. Patient in supine position, Trendelenburg $30^{\circ}$ and lateralized to the right. The pneumoperitoneum up to $12 \mathrm{mmHg}$ by open technique in the right flank was established through a $12 \mathrm{~mm}$ port for the camera and then for the surgeon's left hand. Another $6 \mathrm{~mm}$ port was placed in the right iliac fossa for the surgeon's right hand and a $12 \mathrm{~mm}$ supraumbilical one for the camera. After identification of the rectal stump in the pelvis, the stoma was circumferentially released and a pursestring with polypropylene 2-0 was made. The anvil of a $29 \mathrm{~mm}$ circular stapled device was placed in the colonic end, and then reintroduce into the abdomen. Twoplane parietal closure and reinstallation of the pneumoperitoneum were performed. The transrectal stapled suture was placed through the anterior aspect of the rectal stump, making the end-to-side colorectal anastomosis. The hydropneumatic test was negative. The patient had a postoperative period without complications, being discharged $72 \mathrm{~h}$ after the procedure, tolerating oral diet, without pain, without fever, and after passing stool.

Conclusions: Hartmann's surgery continues to be one of the most performed procedures to treat perforative and occlusive complications of the left colon and rectum. The restitution of intestinal transit after this surgery is not carried out in a very high percentage of cases for different reasons. Mininvasive surgery requires a long learning curve and high-level dexterity, but several studies show that the Hartmann's reversal has better results by this approach.

Key words: Hartmann's Procedure; Laparoscopic Surgery; Minimally Invasive Surgery; Hartmann's Reversal

\section{REFERENCIAS}

1. Hallam S, Mothe BS, Tirumulaju R. Hartmann's procedure, reversal and rate of stoma-free survival. Ann R Coll Surg Engl 2018;100:301-07.

2. Horesh N, Lessing $\mathrm{Y}$, Rudnicki $\mathrm{Y}$, et al. Considerations for Hartmann's reversal and Hartmann's reversal outcomes-a multicenter study. Int J Colorectal Dis 2017;32:1577-82.

3. Melkonian E, Heine C, Contreras D, et al. Reversal of the Hartmann's procedure: A comparative study of laparoscopic versus open surgery. J Minim Access Surg 2017;13:47-50.

4. Resio BJ, Jean R, Chiu AS, Pei KY. Association of timing of colostomy reversal with outcomes following hartmann procedure for diverticulitis. JAMA Surg 2019;154:218-24.

5. Park W, Park WC, Kim KY, Lee SY. Efficacy and safety of laparoscopic hartmann colostomy reversal. Ann Coloproctol 2018;34:306-11.

\section{COMENTARIO}

Es interesante el caso presentado acerca de la reversión de la operación de Hartmann por vía laparoscópica. Esta cirugía representa un desafío para el equipo quirúrgico actuante esencialmente, más allá del tipo de abordaje seleccionado. Es un hecho que la cirugía laparoscópica ha disminuido sustancialmente la morbilidad en la cirugía colorrectal, pero es importante una adecuada selección de pacientes para disminuir al máximo las complicaciones inherentes al método. La reversión de la operación de Hartmann por vía laparoscópica requiere que el equipo quirúrgico en cuestión posea una amplia experiencia en cirugía laparoscópica. Por otro lado, con respecto a los factores dependientes de la selección de pacientes para este abordaje, es importante resaltar el tiempo transcurrido entre la cirugía inicial y la reversión; y el tipo de patología presentada inicialmente (patología benigna o maligna, cirugías previas, defectos parietales coexistentes).

Con respecto a la técnica utilizada por el equipo actuante, es importante resaltar la importancia de un abordaje laparoscópico inicial previo a la liberación del ostoma ya que permite anticipar una adecuada adherenciolisis e identificación del muñón rectal otorgando las condiciones adecuadas para una adecuada confección de una anastomosis técnicamente adecuada.

María Florencia Ventura Clínica Bazterrica. CABA, Argentina. 